\title{
Archaeological Testing of Site 41BX518 and other High-Potential Areas Along FM 2790 in Bexar County, Texas
}

Jerry Henderson

A. Joachim McGraw

Follow this and additional works at: https://scholarworks.sfasu.edu/ita

Part of the American Material Culture Commons, Archaeological Anthropology Commons, Environmental Studies Commons, Other American Studies Commons, Other Arts and Humanities Commons, Other History of Art, Architecture, and Archaeology Commons, and the United States History Commons

Tell us how this article helped you.

This Article is brought to you for free and open access by the Center for Regional Heritage Research at SFA ScholarWorks. It has been accepted for inclusion in Index of Texas Archaeology: Open Access Gray Literature from the Lone Star State by an authorized editor of SFA ScholarWorks. For more information, please contact cdsscholarworks@sfasu.edu. 


\section{Archaeological Testing of Site 41BX518 and other High-Potential Areas Along FM 2790 in Bexar County, Texas}

\section{Licensing Statement}

This is a work produced for the Texas Department of Transportation (TxDOT) by the report producer. TxDOT and the report producer jointly own all rights, title, and interest in and to all intellectual property developed under TXDOT's contract with the report producer. The report may be cited and brief passages from this publication may be reproduced without permission provided that credit is given to both TXDOT and the report producer. Permission to reprint an entire chapter, section, figures or tables must be obtained in advance from either the Supervisor of the Archeological Studies Branch, Environmental Affairs Division, Texas Department of Transportation, 125 East 11th Street, Austin, Texas, 78701 or from the report producer. 


\section{ARCHAFOLOGICAI TESTING OF SITE $413 \times 518$}

AND OTHER HIGH-POTENTIAI AREAS ALONG FM 2790

\section{$\mathbf{I} \mathbf{N}$}

\section{BEXAR COUNTY, TEXAS}

\section{by}

Jerry Henderson and A. Joachim McGraw

TEXAS

STATE DEPARTMENT OF HIGHWAYS AND PUBLIC TRANSPORTATION Highway Design Division 


\begin{abstract}
The State Department of Highways and Public Transportation (SDHPT) conducted archaeological testing along portions of FM 2790 near Elm Creek in southern Bexar County, Texas, in May 1988. Testing was performed to determine whether portions of the previously recorded prehistoric archaeological site of $41 \mathrm{BX} 518$ existed within the right-of-way near the drainage. Results of testing determined that 41 BX518 existed beyond the right-of-way limits of the roadway and no subsurface deposits were identified. No further work is recommended within this portion of FM 2790 and a report of testing follows, including comments on natural soil deposits along this portion of the former terraces adjacent to Elm Creek.
\end{abstract}


TABLE OF CONTENTS

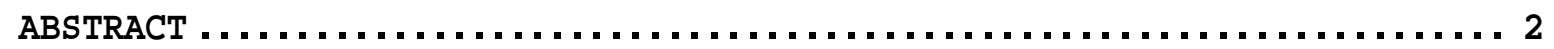

LIST OF FIGURES $\ldots \ldots \ldots \ldots \ldots \ldots \ldots \ldots \ldots \ldots \ldots \ldots \ldots \ldots \ldots \ldots \ldots \ldots \ldots \ldots \ldots$

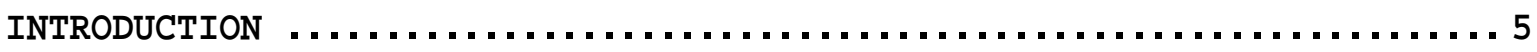

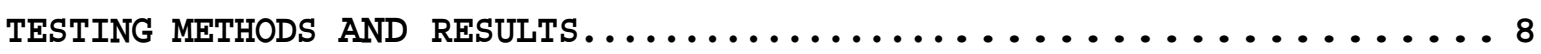

CONCLUSIONS................................... 10

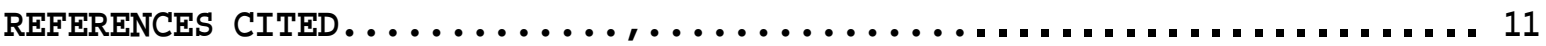




\section{LIST OF FIGURES}

Figure Number

Page

1 Location of FM 2790 and archaeological testing near

Elm Creek, southern Bexar County, Texas...............

2 East wall profile of Backhoe Trench $3 \ldots \ldots \ldots \ldots \ldots \ldots . . . . .9$ 


\section{INTRODUCTION}

The Texas State Department of Highways and Public Transportation (SDHPT) recently initiated archaeological testing along portions of FM 2790, a rural roadway in southern Bexar County, Texas. Testing was conducted in response to a proposed bridge construction at the intersection of Elm Creek and FM 2790 as well as the widening of the roadway within the existing right-of-way (see Figure 1).

The archaeological investigations, which consisted of intensive survey and both mechanical and hand testing, was directed toward two cultural resources objectives: (1) subsurface examination of the roadway adjacent to the previously recorded prehistoric site of 41BX518; and (2) an assessment of any identified cultural deposits and their significance to the local and regional archaeological record. The area surrounding $41 \mathrm{BX} 518$ was considered to be a locale of high archaeological potential as significant buried cultural materials might be associated with the locally prominent knoll land form.

This report presents the results of limited testing within selected portions of the FM 2790 roadway conducted by A. Joachim McGraw of the SDHPT cultural resources staff during May 10-11 and May 16-19, 1988. Field support was provided by the SDHPT District 15 maintenance office in southwestern Bexar County. A total of 8 person-days was expended during the testing period and included hand-excavated units, and backhoe and Gradall machine trenching.

All work was performed in accordance with $36 \mathrm{CFR}$, Part 80, procedures prescribed and endorsed by the Federal Highway Administration, and also followed the guidelines presented in the Council of Texas Archeologists professional performance standards (Council of Texas Archeologists 1985). As both federal and state funding was involved in various segments of the project, assessments of cultural resources significance were directed toward site potential for eligibility to the National Register of Historic Places as well as recognition toward State Archeological Landmark status.

The results of fieldwork indicated that: (1) no subsurface deposits related to the nearby site of 41 BX518 were found within the FM 2790 right-of-way adjacent to the identified site area; and (2) mechanical testing along previously identified terrace margins of the past stream channel did not expose buried cultural deposits within the boundaries of the roadway. Collected data indicated no potential for surface or subsurface archaeological sites that may be eligible for nomination to the National Register of Historic Places or as State Archeological Landmarks. Testing did indicate the viability of pursuing future research along recognized fossil terrace margins within this portion of the lower Medina River valley as additional developmental impacts occur. 
This reports presents a summary of work accomplished, recommendations for no further work along this portion of FM 2790, and a description and comments of the natural stratigraphy and soil deposits uncovered during testing operations. 
This Page Redacted Per THC Policy 


\section{TESTING METHODS AND RESULTS}

The prehistoric archaeological site of 41BX518 was first recorded in 1981 by A. McGraw of the University of Texas at San Antonio (UTSA) during a cultural resources survey for the proposed Applewhite Reservoir. Originally described as a moderate scatter of chipped stone and fire- reddened rock along the terrace slopes on the north bank of Elm Creek, further work was recommended in the form of limited testing to determine the site's eligibility to the National Register of Historic Places. The actual margin of the site was poorly defined at that time because modern alterations in the form of a farm/ranch complex, county road construction, and adjacent agricultural clearing had extensively modified the landscape.

Given the poorly defined site margin, the proximity of the site area to FM 2790, and the proposed modifications, intensive survey and limited testing was considered appropriate to investigate buried site potential within the adjacent FM 2790 right-of-way.

The portion of a small knoll about 4 meters above and 300 meters north of the present Elm Creek channel appeared to represent the extreme northwestern margin of 41BX518. Following a systematic pedestrian survey throughout a .5 $\mathrm{km}$ distance from the Elm Creek intersection, limited hand and mechanical testing was initiated to sample subsurface deposits.

The margin of the small knoll parallel to the roadway, approximately 130 meters in length, was investigated by three backhoe trenches spaced at ca. 50 meter intervals. Each trench, roughly 1 x 4 meters in length, was excavated to a depth of 1.5 to 2.0 meters. Throughout the testing, emphasis was placed upon the western portion of the right-of-way as it was less disturbed. The more narrow eastern segment of the roadway which was closest to the identified site area of 41BX518 was not tested as it included utility easements and driveways.

Additionally, to more systematically investigate the locale, a 1-meter square test unit was hand-excavated to a depth of $50 \mathrm{~cm}$ and the materials screened through 114-in. wire mesh. The test unit was located adjacent to the western right-of-way fence line along the crest of the knoll.

In all the mechanically excavated trenches and the hand-dug test unit, an almost impenetrable clay hardpan, or subsoil, was encountered within 25 cm of the surface. No cultural materials in $t$ he form of lithic debris or firereddened limestone rock, or other indications of prehistoric activities, such as clusters of Rabdotus snail shells, were noted. Soil deposits in all trenches were characterized by a yellowish brown, unconsolidated silty loam topsoil (10YR5/6) that varied in depth from 10 to $27 \mathrm{~cm}$. A clayey, large subangular blocky matrix somewhat lighter in color (10YR6/6) underlay the more recent deposits to a depth of $30-40 \mathrm{~cm}$ below the surface. A slightly less 
compacted, less blocky, brown colored soil deposit extended from 40-80 cm. Small caliche intrusions were observed from a depth of $50 \mathrm{~cm}$ to approximately $110 \mathrm{~cm}$ below the surface. A loose, reddish yellowish, silty matrix composed the lower subsoil deposits to a depth of $200 \mathrm{~cm}$. A typical backhoe trench wall section is illustrated in Figure 2.

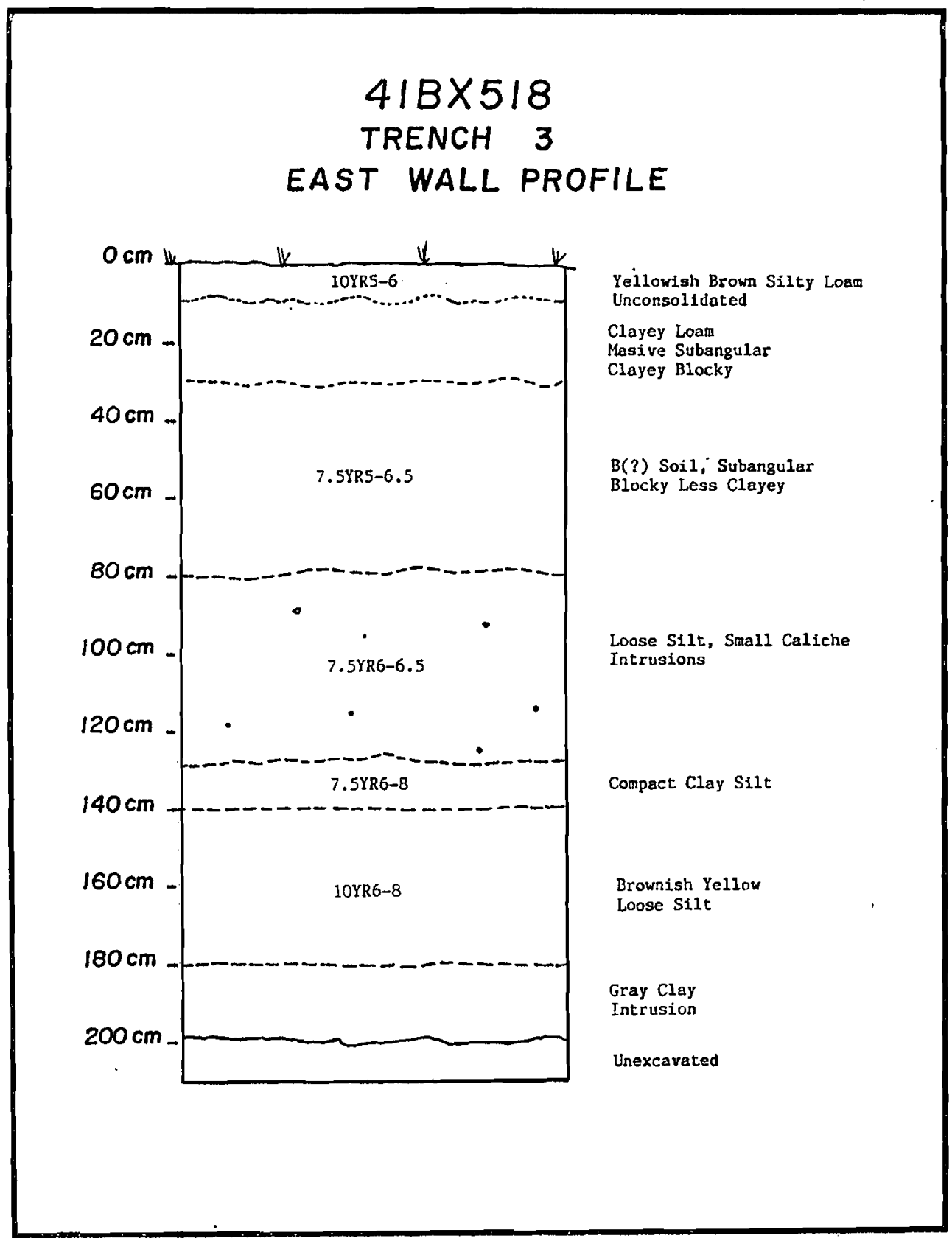

Figure 2. East Wall Profile of Backhoe Trench 3. 


\section{CONCLUSIONS}

The lack of cultural materials in a subsurface context and the paucity of surface materials in the form of an occasional burned rock suggest that this locale comprised only the margins of a prehistoric activity area that was centered to the southeast and well beyond the impacted area of the roadway. It is possible, if not probable, that the shallow compacted clay deposit represents erosional sequences from the knoll's slopes that have extensively disturbed original stratigraphic contexts.

Although considered a negative testing report, it is believed that the natural soil deposits as observed within the wall profiles of machine-excavated trenches may offer future researchers in this area some further insights into subsurface deposits of 41BX518 and other nearby archaeological locations.

Given the lack of intact or recognizable subsurface cultural materials, the identification of a prehistoric activity area well beyond the right-of-way limits of FM 2790, and the extent of negative limited testing to date, it is believed that this portion of $41 \mathrm{BX} 518$ does not meet the criteria of eligibility for nomination to the National Register of Historic Places and no further work is recommended along this segment of FM 2790. 
$41 \mathrm{BX} 518$

\section{REFERENCES CITED}

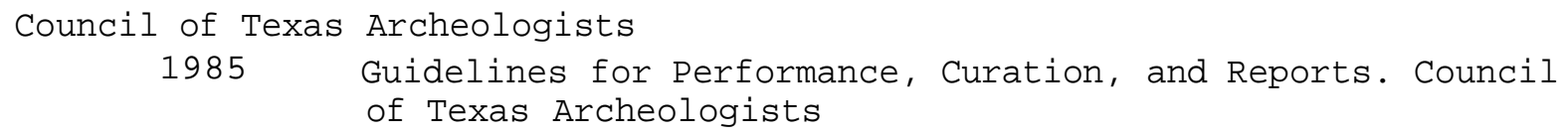

